\title{
Ownership structure and environmental, social and governance performance disclosure: the moderating role of the board independence
}

\author{
Hamzeh Al Amosh \\ Ministry of Education and Higher Education Qatar, Doha, Qatar, and \\ Saleh F.A. Khatib \\ Azman Hashim International Business School, Universiti Teknologi Malaysia, \\ Johor Bahru, Malaysia
}

\begin{abstract}
Purpose - The current study dealt with the ownership structure effect as a potential determinant of the environmental, social and governance (ESG) performance disclosure in the Jordanian context.

Design/methodology/approach - Using the content analysis technique, data were collected and analyzed from a final sample of 51 annual reports of Jordanian industrial companies listed for 2012-2019.

Findings - The results show that foreign ownership and state ownership play a critical role in disclosing the ESG performance. Also, the board's independence plays an influential role in improving disclosure quality, enhancing family ownership in disclosure. It also limits the negative role of block holder ownership and managerial ownership on the ESG disclosure.

Originality/value - To the best of the authors' knowledge, this is the first study that deals with the role of ownership structure on the ESG disclosure level separately and collectively through the moderating role of board independence.
\end{abstract}

Keywords Ownership structure, Board independence, ESG disclosure, Stakeholders, Legitimacy

Paper type Research paper

\section{Introduction}

In recent decades, the disclosure landscape evolution in a context of well-established interest toward non-financial information at a global level gave rise to many concepts related to social, economic, and environmental issues that have surfaced as a reaction to corporate practices and their effect on the environment in which they operate. Therefore, many stakeholders took the initiative to take an approach to corporate accountability for their role and the extent of their contribution to meeting their aspirations (Manes-Rossi et al., 2018). At the same time, companies realized the potential consequences of this. They began to think about the most appropriate means to meet various stakeholders' aspirations. Thus, the companies' activities and practices became subject to continuous monitoring by the stakeholders, prompting companies to contribute to activities that stakeholders favor.

According to stakeholder theory, companies must consider all stakeholder demands to legalize their activities (Al Amosh and Mansor, 2018; Deegan, 2002). Disclosure of information

(C) Hamzeh Al Amosh and Saleh F.A. Khatib. Published in Journal of Business and Socio-economic Development. Published by Emerald Publishing Limited. This article is published under the Creative Commons Attribution (CC BY 4.0) licence. Anyone may reproduce, distribute, translate and create derivative works of this article (for both commercial and non-commercial purposes), subject to full attribution to the original publication and authors. The full terms of this licence may be seen at http:// creativecommons.org/licences/by/4.0/legalcode

Ownership structure and board independence 
JBSED

2,1

50

related to companies' activities is one of the stakeholders' demands, and it is also a means of communication with various stakeholders. Besides, satisfying stakeholders' desires also spares companies from further pressures that they may face, in addition to working to narrow the legitimacy gap between stakeholders and companies (Al Amosh and Mansor, 2020). So, the issues related to sustainability fall within stakeholders' interests (Khatib et al., 2021; Hörisch et al., 2020), and this gives companies an excellent opportunity to gain trust and enhance legitimacy.

In Jordan, the government started to motivate companies to engage in sustainability disclosure activities, as the Amman Stock Exchange joined the United Nations Sustainable Stock Exchanges initiative as part of a comprehensive strategy to improve the performance of the financial market (Amman stock exchange, 2016), this follows the launch of a government plan to promote sustainable development in the country, the plan includes social, economic and environmental goals called "Jordan 2025" (Al Amosh, 2021), To face the recent crises that Jordan is going through, such as the humanitarian displacement due to the political conditions in neighboring countries and the challenging social, environmental and economic situations that need radical solutions.

Corporate ownership structures are one of the indicators that describe a company's identity. Also, the corporate ownership structure contributes to institutional oversight and affects companies' motives in disclosing information (Eng and Mak, 2003). Legal regulations require all listed Jordanian companies to disclose ownership structure details in their annual reports. According to Alzoubi (2016), Jordan has a high concentration of ownership. It is a factor influencing corporate decisions; it is also considered one of the tools of governance parallel to legal regulations. Thus, this is the leading research catalyst for the current study.

The study examines the impact of the ownership structure, including foreign ownership, state ownership, managerial ownership, block-holder ownership, and family ownership, on the level of sustainability performance disclosure (including environmental, social, and governance), using a sample of listed Jordanian industrial companies. The current paper carries many contributions. In theory, this study expands the theoretical framework of stakeholder theory and legitimacy theory by providing insights on the interaction of independent boards with the demands of legitimacy and stakeholders despite the possibility of a conflict of interest with the owners and their role in the ESG practices (Zamil et al., 2021). In practice, the study provides an in-depth look at the reality of the ownership structure within Jordanian companies and the extent of their influence on ESG disclosure. Moreover, the current study provides insight about independent boards and how they manage relationships with stakeholders and the legitimacy agenda with a diversity of owners. Hence, the study adds to the existing literature new evidence about the relationship between companies' ownership structures and the boards' independence and practices of disclosing ESG performance.

The rest of the paper is structured as follows: Section 2 sheds light on the theoretical framework. Section 3 reviews the literature and the hypotheses development. Section 4 includes the methodology. Section 5 reflects the results and discussion-finally, the conclusions.

\section{Theoretical framework}

The disclosure phenomenon has been discussed in several related theories, such as stakeholder theory and legitimacy theory (Zamil et al., 2021). The stakeholder theory argues that companies practice disclosing information to meet their stakeholders' expectations (A1 Amosh and Mansor, 2021). According to Pajuelo Moreno and Duarte-Atoche (2019), companies are beginning to realize the importance of disclosing sustainability issues to stakeholders. Also, non-financial issues receive significant attention from various 
stakeholders (Schaltegger et al., 2006), which led to increased companies' awareness of the importance of disclosing sustainability issues to stakeholders (Pajuelo Moreno and DuarteAtoche, 2019).

Stakeholders' interest in sustainability and related social and environmental issues is considered ethical issues (Eugénio et al., 2013). This is consistent with Deegan and Unerman's (2006) suggestions that companies should take an ethical approach to deal with stakeholders by promoting transparency and disclosure. Therefore, firms began adopting serious disclosure strategies that took into account stakeholder pressure and legitimacy concerns (Negre et al., 2017), including disclosure of its performance in the field of sustainability.

Disclosure of sustainability performance is an effective way to communicate with various stakeholders (Bae et al., 2018); It influences stakeholder attitudes toward corporate practices and maximizes the value of various stakeholders (Hörisch et al., 2020). Therefore, companies should improve their disclosure practices to meet stakeholders' information needs (Al Amosh and Mansor, 2020). Avoid any possible confrontation with stakeholders, and address current stakeholders' demands and legitimation by strengthening disclosure strategy (Patten, 2019).

On the other hand, the legitimacy theory is considered one of the most common theories in the disclosure literature (Campbell et al., 2003; Deegan, 2002; Zamil et al., 2021). Where the legitimacy theory states that "organizations continually seek to ensure that they are perceived as operating within the bounds and norms of their respective societies - that is, they attempt to ensure that outside parties perceive their activities as being "legitimate" (Deegan, 2013, p. 343).

According to Suchman (1995), the entities should act according to prevailing social order, values, and norms. Accordingly, the actual disparity between the entity's behavior and the overall value system threatens its legitimacy (Lindblom, 1994). There was a significant focus on the concept of the "legitimacy gap," which occurs when companies violate the prevailing value system in communities, as the widening legitimacy gap is a real threat to the company's existence (Moloi and Marwala, 2020). Therefore, companies are taking proactive initiatives to legitimize their existence and avoid a legitimacy gap. Among the most important of these initiatives is engaging in sustainability-related activities and disclosing them to the stakeholders and public (Ching and Gerab, 2017).

\section{Literature review and hypotheses development}

According to Iannotta et al. (2007), the ownership concept structure falls within two main concepts: the degree of ownership concentration and the nature of the owners. In this regard, the literature dealt with the relationship between ownership structure and disclosure. Consequently, the current study will examine a set of suggested factors and their impact on ESG disclosure.

\subsection{Foreign ownership}

Foreign shareholders are essential pillars of achieving transparency and trust between companies and stakeholders (Al Amosh and Mansor, 2021). The presence of foreign ownership also enhances stakeholders' aspirations (Suchman, 1995; Arouri et al., 2014); this gives legitimacy to the company's activities (Alkhawaldeh, 2012). Moreover, foreign expertise may direct the company's policies towards a specific agenda, such as sustainability.

The literature presented mixed evidence regarding the relationship between foreign ownership and information disclosure. In Jordan, Alhazaimeh et al. (2014) argued that foreign ownership positively affected voluntary disclosure practices for companies, while Abu Qa'dan and Suwaidan (2019) claimed a negative relationship between foreign ownership and disclosure of corporate social responsibility in Jordan. In another context, Guo and Zheng (2021) investigated a set of proposed variables as determinants of corporate social

\section{Ownership structure and board independence}


JBSED 2,1

responsibility in China. The results yielded that foreign ownership has a positive impact on the disclosure level. These results were supported by Barako et al. (2006) and Grassa et al. (2020).

In contrast, Saini and Singhania (2019) reported a negative relationship between foreign ownership and information disclosure. Likewise, Sharma et al. (2020) suggested an adverse effect of foreign owners in companies on disclosure. On the other hand, these allegations have been refuted before Adeniyi and Adebayo (2018), Mahmood et al. (2017), and Rustam et al. (2019), where they indicated that the foreign ownership factor plays a critical role in motivating companies to engage in and report on sustainability activities.

Consequently, foreign ownership can enhance corporate governance and maximize stakeholders' value by pushing corporate administrations to respond to their demands and aspirations, including companies' performance disclosure in the field of sustainability. Therefore, the following hypothesis was developed:

H1. There is a positive effect of foreign ownership on the level of ESG disclosures.

\subsection{State ownership}

State ownership refers to the number of state-owned shares in a company, as governments invest in companies to achieve their goals and promote development. According to Monk (2009), state ownership improves legitimacy by enhancing corporate transparency and accountability. Likewise, the diversity of ownership parties is in the interest of stakeholders (Hazaea et al., 2021). This reinforces the stakeholders' demands to disclose information and concern to them, such as sustainability. Also, the government considers disclosure a priority for stakeholders (Eng and Mak, 2003). This supports the ethical system of companies that contribute owned by the government.

Previous literature discussed the relationship between the state ownership factor and the information disclosure level. However, is still a lack of evidence presented (Lagasio and Cucari, 2019). Rudyanto (2017) suggests that state ownership plays a critical role in improving sustainability disclosure quality. Khan et al. (2013) also trusted that companies that include public ownership aspire more to achieve the aspirations of society and achieve legitimacy, which enhances social responsibility and its disclosure, where the government put pressure on the corporate boards to strengthen social and environmental responsibility for companies (Khlif et al., 2017). Moreover, a set of researchers also supported the positive effect of state ownership on disclosure practices (e.g. Albawwat and Basah, 2015; Alhazaimeh et al., 2014). While Al-Janadi et al. (2016) suggested a negative effect of state ownership on the disclosure level. In line with the literature, the study proposes the following hypothesis:

H2. There is a positive effect of state ownership on the level of ESG disclosures.

\subsection{Managerial ownership}

According to stakeholder theory, management practices influence stakeholder attitudes, where the public of stakeholders demands corporate departments to constantly meet their aspirations for information. On the other hand, managerial ownership represents the share of executives owning the company's shares (Samaha and Dahawy, 2011). In this regard, this results in management interests that may or may not coincide with the aspirations of the rest of the stakeholders. It has been suggested that managerial ownership is likely to play an influential role in bringing the convergence views between corporate management and other stakeholders which affects the company's performance (Oanh et al., 2021).

In the context of literature, Juhmani (2013) mentioned that managerial ownership has no impact on the Bahraini companies' practices in the voluntary disclosure. Lagasio and Cucari (2019) also argued that managerial ownership does not improve ESG's disclosure quality. 
Khan et al. (2013) also found that managerial ownership enables the management to dominate the company's decisions and push towards limiting participation in social activities to reduce costs, which will negatively affect social responsibility disclosure. In contrast, Li et al. (2018) claimed a linear relationship between managerial ownership and disclosure. As a result, it is possible that the interests of management do not coincide with the interests of stakeholders and that the hegemony of management may limit investment in issues related to sustainability, so the following hypothesis was suggested:

H3. There is no effect of managerial ownership on the level of ESG disclosures.

\subsection{Block-holder ownership}

The block-holder ownership expresses the owners typically own to $5 \%$ or more of the company's number of issued shares (Al Amosh and Mansor, 2020; Juhmani, 2013). Block holders constantly try to influence the company's decisions by directing it to engage in a specific agenda (Al-Janadi et al., 2016). This agenda can be consistent with the stakeholders' aspirations, and the stakeholder perspective argues that management is subject to the demands of stakeholders who have a larger share in the company (Juhmani, 2013). On the other hand, the block holders may restrict the disclosure of information (Raimo et al., 2020), which leads to the emergence of information inconsistency. On the other hand, Samaha et al. (2012) believe that the block holder ownership presence contributes to strengthening corporate governance.

Most of the literature suggested the absence of a relationship or negative relationship between the block holder's ownership and the disclosure level, as in a study conducted by Eng and Mak (2003) in Singapore, it was found that there is no link between the ownership of the block holder and the disclosure. In contrast, Juhmani (2013) indicated the block holder's ownership plays a negative role in voluntary disclosure practice. The owners of the blocks try to monopolize the information to maintain their information excellence (Sengupta, 2004). Elfeky (2017) also documented the negative impact of the block holder's ownership on the disclosure, and this evidence was supported by Kolsi (2017). Yu et al. (2020) took an opposing stance, claiming a positive correlation to the block holder's ownership on disclosure. From the preceding, the block holder may carry a particular agenda that may conflict with the interests of the public of stakeholders (Younas et al., 2021). The block holder may monopolize the information to distinguish it from the rest of the stakeholders. Also, the block holder ownership dispersion positively affects the information asymmetry (Shin et al., 2020). Hence, the study hypothesized that:

H4. There is no effect of block-holder ownership on the level of ESG disclosures.

\subsection{Family ownership}

Family ownership is defined as the percentage of ownership by a family or family members of shares in a company. The presence of shares owned by the family contributes to controlling the management's behavior and decreases its discretion (Bansal et al., 2018). According to Ilhan-Nas et al. (2018), family ownership owners seek to achieve their demands through internal corporate governance and informal relationships. If family ownership is high, pressure will increase to enforce their rights, and this will subject the management to the demands of family ownership to maintain their positions. This dominance will direct corporate strategies towards bias toward family owners and no other shareholders and stakeholders (Khan et al., 2013). This will neglect many of the issues that various stakeholders are looking forward to.

There is a scarceness of literature that has examined the relationship between family ownership and the ESG disclosure, as Lagasio and Cucari (2019) argue that there are still

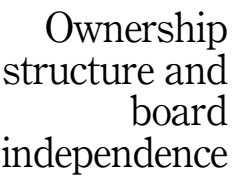


JBSED

2,1

54

hesitations regarding the impact of family ownership on disclosing ESG. Generally, Chau and Gray (2010) report that family ownership has a significant effect on voluntary disclosure practices in Hong Kong, and it also contributes to enhancing transparency and reducing information asymmetries. Jalila and Devi (2012) believe that companies with more family ownership have no strong incentive to disclose information. In contrast, Rees and Rodionova (2015) claimed that family ownership negatively impacts the company's ESG performance. Furthermore, Rudyanto (2017) documented that family ownership does not influence the quality of sustainability disclosure. The literature produced inconsistent evidence regarding the effect of family ownership on disclosure, providing an incentive for further research.

On the one hand, family ownership may have an active role in establishing common interests with other stakeholders and meeting many common goals. On the contrary, family ownership may be opportunistic. Therefore, the following hypothesis has been formulated:

H5. There is no effect of family ownership on the level of ESG disclosures.

\subsection{The moderating role of board independence}

It is typical for the board's independence to enhance good governance in companies, where decisions are taken without bias or personal interests (Romano et al., 2020; Jizi, 2017). Independent boards also contribute to a more significant oversight role on corporate performance (Fuzi et al., 2016). Moreover, Independent boards also limit the negative impact of ownership, such as family ownership, on disclosure practices (Chau and Gray, 2010). This enhances transparency and trust and ensures that stakeholders' demands are taken into consideration. According to the legitimacy perspective, the board of directors' independence stimulates social responsibility disclosure, enhancing the sustainability of the company's activities (Fernández-Gago et al., 2018). Accordingly, it is expected that more independent boards of directors will tend to meet the aspirations of various stakeholders and consider the means that guarantee the company's legitimacy in the environment in which it operates.

In the relevant literature, Zaid et al. (2020) argued that board independence plays a crucial mediating role in promoting corporate social responsibility, as its positive impact on foreign ownership and government ownership is reflected in Palestinian companies' disclosure practices. Cucari et al. (2018) added that boards of more independent directors are likely to be more invested in sustainability activities in a study they conducted in Italy. Also, Husted and de Sousa-Filho (2019) state that companies with high independence boards are more likely to be involved in ESG activities. While Pucheta-Martínez and Gallego-Álvarez (2019) presented a different point of view, as they argued that the board of directors' independence does not motivate companies to disclose, and this prediction was supported by Khan et al. (2021). On the contrary, Ortas et al. (2017) indicated through an analysis of 87 published research papers that the high percentage of independent directors in companies encourages them to adhere to stakeholders' demands and ESG criteria. As a result, the study suggested the following hypotheses:

H6a. The effect of foreign ownership on the level of ESG disclosures is moderated by board independence.

H6b. The effect of state ownership on the level of ESG disclosures is moderated by board independence.

H6c. The effect of managerial ownership on the level of ESG disclosures is moderated by board independence.

H6d. The effect of block-holder ownership on the level of ESG disclosures is moderated by board independence. 
H6e. The effect of family ownership on the level of ESG disclosures is moderated by board independence.

\section{Methodology}

\subsection{Sampling and data collection}

The current study's statistical population included all Jordanian industrial listed companies on the Amman Stock Exchange (ASE) between 2012 and 2019, a total of 62 companies. Eleven companies were excluded due to the unavailability of their data over the study period. Thus, the final sample became 51 companies, and it constitutes approximately $82 \%$ of the total population of the study. In addition, 408 observations were collected for statistical analysis.

\subsection{Data analysis}

The current study relied on the content analysis technique to explore the ownership structure impact on the ESG disclosure, where the published annual reports of the listed Jordanian industrial companies published were examined and relevant data extracted through the panel data approach, which is the most appropriate method for the current study (Krippendorff, 2018; Lu et al., 2017). Moreover, several disclosure literatures relied on this method (e.g. Romano et al., 2020; Saini and Singhania, 2019).

\subsection{Research model}

The following regression equations by two models were developed to investigate the effect of the ownership structure variables on the level of total ESG disclosure, and their environmental, social and governance dimensions:

\section{Model 1}

$$
\begin{aligned}
\text { Disclosure }= & \alpha+\beta_{0}+\beta_{1} \mathrm{FOROWN}+\beta_{2} \mathrm{STAOWN}+\beta_{3} \mathrm{MANOWN}_{i t}+\beta_{4} \mathrm{BLKOWN} \\
& +\beta_{5} \mathrm{FAMOWN}+\beta_{6} \mathrm{COSIZ}+\beta_{7} \mathrm{COAGE}+\beta_{8} \mathrm{COTYP}_{i t}+\varepsilon
\end{aligned}
$$

The moderating role of board independence with the ownership structure effect on ESG disclosure is examined by the following regression model:

\section{Model 2}

$$
\begin{aligned}
\text { Disclosure }= & \alpha+\beta_{0}+\beta_{1} \mathrm{FOROWN}+\beta_{2} \mathrm{STAOWN}+\beta_{3} \mathrm{MANOWN}_{i t}+\beta_{4} \mathrm{BLKOWN} \\
& +\beta_{5} \mathrm{FAMOWN}+\beta_{6} \mathrm{BOIND}+\beta_{7} \mathrm{COSIZ}+\beta_{8} \mathrm{COAGE}+\beta_{9} \mathrm{COTYP}_{i t}+\varepsilon
\end{aligned}
$$

where disclosure refers to three environmental (ENVD), social (SOCD), governance (GOVD), and total sustainability performance disclosure (ESGD). The current study is based on the checklist of recommended sustainability metrics by the Amman Stock Exchange as a proxy for the dependent variable (disclosure), and it is derived from the guidelines issued by Global Reporting Initiative (GRI). The checklist consists of 28 indicators, 7 environmental, 13 social and 8 governance indicators, as provided in Table 1 . Table 2 provides a summary of the research variables. 


\section{JBSED 2,1}

Social performance disclosure

Governance performance disclosure

Table 1.

ESG disclosure elements
Total sustainability performance disclosure

\section{Code Data coverage}

ENVD

Direct and indirect energy consumption, energy intensity, primary energy source, water management, waste management, environmental policy, environmental impacts

SOCD CEO pay ratio, gender pay ratio, employee turnover rate, gender diversity, nondiscrimination, injury rate, child labor, human rights policy, board- diversity, donations, employee qualification, community work, health

GOVD Board- separation of powers, confidential voting, incentivized pay, fair labor practice, supplier code (SC) of conduct, ethics code (EC) of conduct, bribery/anticorruption code (BAC), tax transparency

ESGD Environmental, social, and governance performance disclosure
Operationalization

Dummy 1 for disclosing the item and 0 otherwise

Dummy 1 for disclosing the item and 0 otherwise

Dummy 1 for disclosing the item and 0 otherwise

Dummy 1 for disclosing the item and 0 otherwise

Independent and control variables

\begin{tabular}{|c|c|c|}
\hline Variable & Code & Operationalization \\
\hline Foreign ownership & FOROWN & $\begin{array}{l}\text { The percentage of the shares owned by foreigners to the total number } \\
\text { of issued shares }\end{array}$ \\
\hline State ownership & STAOWN & $\begin{array}{l}\text { The percentage of state-owned shares to the total number of issued } \\
\text { shares }\end{array}$ \\
\hline $\begin{array}{l}\text { Managerial } \\
\text { ownership }\end{array}$ & MANOWN & $\begin{array}{l}\text { The percentage of shares owned by CEO and executive directors to the } \\
\text { total number of shares }\end{array}$ \\
\hline $\begin{array}{l}\text { Block-holder } \\
\text { ownership }\end{array}$ & BLKOWN & Owners $5 \%$ or more of a total shares \\
\hline Family ownership & FAMOWN & Percentage of family-owned shares to total issued shares \\
\hline Board independence & BOIND & $\begin{array}{l}\text { Percentage of independence directors on the board } \\
\text { Control variables }\end{array}$ \\
\hline Company size & COSZE & The natural logarithm of total assets \\
\hline Company age & COAGE & Number of years since foundation \\
\hline $\begin{array}{l}\text { Company type of } \\
\text { industry }\end{array}$ & COTYP & The type of sub-sectors \\
\hline
\end{tabular}

\section{Results and discussion}

\subsection{Descriptive results}

Table 3 shows a summary of the variable's descriptive statistics. The analysis indicates that foreign investment is still in its infancy in Jordan, where the average foreign ownership amounted to (mean $=28.54 \%$ ), while the minimum of state ownership is 0.00 . The maximum was 96.9 with a (mean $=11.73 \%$ ), it was that there seem to be companies that the government owns most of its shares, while the average of managerial ownership is (mean $=10.21 \%$ ). In comparison, the average of block holder ownership has reached (mean $=58.33 \%$ ), which indicates significant concentration ownership in many companies. Also, family ownership appears at a relatively small average of (mean $=19.61 \%$ ), as it does not seem that the public shareholding industrial companies' sector is witnessing family domination. 


\begin{tabular}{|c|c|c|c|c|c|c|}
\hline Variables & Obs. & Minimum & Maximum & Mean \% & SD \% & $n$ \\
\hline FOROWN & 408 & 0.00 & 37.8 & 28.54 & 6.47 & )arc \\
\hline STAOWN & 408 & 0.00 & 96.9 & 11.73 & 16.32 & \\
\hline MANOWN & 408 & 0.00 & 25.61 & 10.21 & 21.14 & 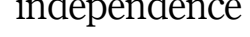 \\
\hline BLKOWN & 408 & 5.00 & 100.00 & 58.33 & 18.9 & \\
\hline FAOWN & 408 & 0.00 & 89.24 & 19.61 & 16.92 & \\
\hline BOIND & 408 & 44.00 & 100 & 74.68 & 16.64 & \\
\hline COSZE & 408 & 4.27 & 9.86 & 7.15 & 9.58 & \\
\hline COAGE & 408 & 10 & 64 & 30.19 & 14.88 & \\
\hline ENVD & 408 & 6 & 62 & 36.72 & 12.56 & \\
\hline SOCD & 408 & 19 & 77 & 41.68 & 14.21 & \\
\hline GOVD & 408 & 22 & 72 & 37.24 & 11.86 & Table \\
\hline ESGD & 408 & 16 & 69 & 38.37 & 11.09 & Descriptive statist \\
\hline
\end{tabular}

Moreover, the board independence appears on average (mean $=74.68 \%$ ). That is, most companies have independent boards. On the other hand, the environmental disclosure shows an average (mean $=36.72 \%$ ), the social is (mean $=41.68 \%$ ). The governance is (mean $=37.24 \%$ ), while the average of the sustainability disclosure as a whole is (mean $=38.37 \%$ ). This indicates that industrial companies comply with disclosing their sustainability performance and dimensions close to the average, but there could be room for improvement in the future.

\subsection{Regression analysis results}

As shown in Table 4, VIF values ranged between 1.09 and 1.52. Thus, the results point out that there is no multicollinearity between the variables, as all values are less than 10 (Akinwande et al., 2015; Myers, 1990). Therefore, those results are considered positive for the current study data. Using a pair-wise correlation, multicollinearity was tested. According to Gujarati et al. (2012), a multicollinearity problem may exist if a coefficient correlation is higher than 0.8. Looking at the Table 4 results, all the independent variables are less than 0.8 , which indicates that all the variables are not correlated and that there is no multicollinearity issue in the current study.

It seems that foreign ownership and state ownership enhance the disclosure of the performance of companies in the field of sustainability in all its environmental, social, and governance dimensions, as it seems that foreign expertise is an essential factor in promoting sustainability disclosure practices in emerging economies, this result is the line with the evidence provided by several researchers (e.g. Alhazaimeh et al., 2014; Adeniyi and Adebayo, 2018; Mahmood et al., 2017; Rustam et al.,2019). On the other hand, the results were not agreed with (Abu Qa'dan and Suwaidan, 2019; Saini and Singhania, 2019; Sharma et al., 2020). According to Table 5, state ownership plays a decisive role for companies in the disclosure of sustainability due to the fact that the companies in which the state contributes respond to government strategies aimed at promoting sustainable development, as government pressures seem to be in line with the interests of stakeholders, and this is what was indicated in previous literature (e.g. Rudyanto, 2017; Khan et al., 2013).

On the other hand, the findings show no impact of managerial ownership on the total ESG disclosure. This may be due to a conflict of interest that negatively affects good governance, the owner-managers may decide based on Its interests, managers who own stakes in the company may not pay any attention to the sustainability agenda and related issues. These findings are consistent with Lagasio and Cucari (2019) regarding the ESG disclosure and with Juhmani (2013) concerning its general disclosure practices. As expected, block holder ownership negatively affects the sustainability disclosure with its all dimensions, and it 
JBSED

2,1

58

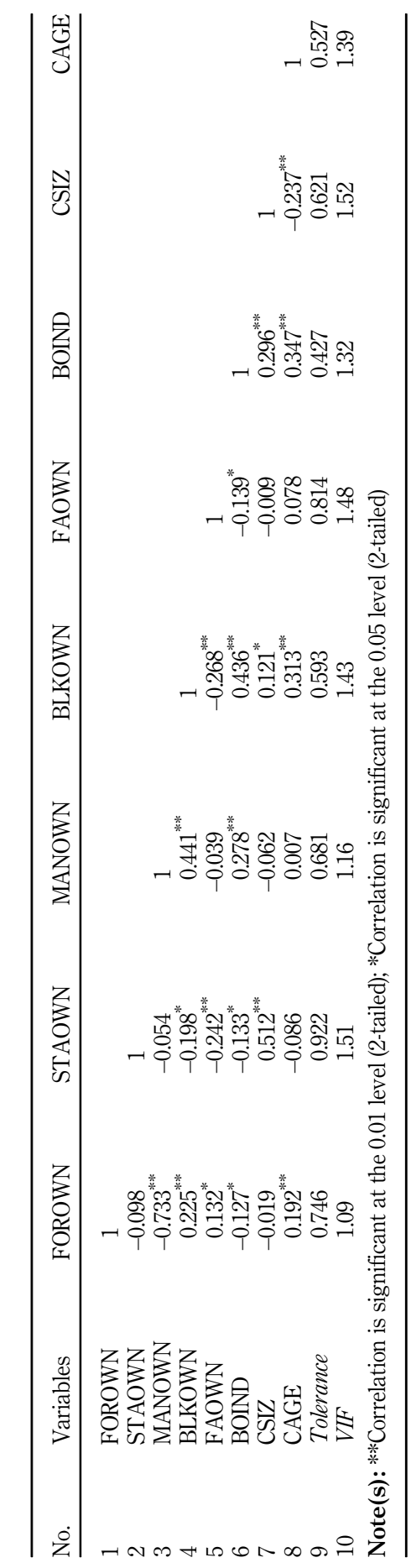

Table 4.

Correlation and

multicollinearity

analysis results for independent variables 


\begin{tabular}{|c|c|c|c|c|c|c|c|c|c|}
\hline \multirow[b]{2}{*}{ Independent variables } & \multicolumn{2}{|c|}{ ENVD } & \multicolumn{2}{|c|}{ SOCD } & \multicolumn{2}{|c|}{ GOVD } & \multicolumn{2}{|c|}{ ESGD } & \multirow{2}{*}{$\begin{array}{l}\text { Ownership } \\
\text { structure and }\end{array}$} \\
\hline & Coef. & Sig. & Coef. & Sig. & Coef. & Sig. & Coef. & Sig. & \\
\hline FOROWN & 2.622 & $0.047 *$ & 1.661 & $0.026^{*}$ & 1.583 & $0.041^{*}$ & 1.797 & $0.012^{*}$ & \\
\hline STAOWN & 1.949 & $0.018 *$ & 1.466 & $0.039 *$ & 1.329 & $0.007 *$ & 1.793 & $0.042 *$ & $n$ \\
\hline MANOWN & -2.506 & 0.509 & -1.791 & 0.731 & -2.391 & 0.722 & -2.289 & 0.594 & \\
\hline BLKOWN & -2.163 & $0.019 *$ & -2.155 & $0.045^{*}$ & -1.863 & $0.021^{*}$ & -2.943 & $0.034^{*}$ & \\
\hline FAOWN & -1.637 & 0.364 & 1.447 & 0.758 & 2.171 & 0.629 & 1.828 & 0.565 & \\
\hline COSZE & 4.277 & $0.011 *$ & 3.912 & $0.037 *$ & 3.193 & $0.003 * *$ & 3.274 & $0.013^{*}$ & \\
\hline COAGE & 0.985 & 0.174 & 0.792 & 0.326 & 0.843 & 0.656 & 0.738 & 0.498 & \\
\hline Year dummies & Include & & Include & & Include & & Include & & \\
\hline Industry dummies & Include & & Include & & Include & & Include & & \\
\hline Constant & 0.273 & $0.000 * *$ & 0.259 & $0.000 * *$ & 0.266 & $0.000^{* * *}$ & 0.245 & 0.29 & \\
\hline Adj. $R$ square $\left(R^{2}\right)$ & $0.387 * *$ & & $0.319 * *$ & & $0.342^{* *}$ & & $0.401 * *$ & & \\
\hline$F$-statistics & 16.76 & & 6.87 & & 5.83 & & 9.146 & & \\
\hline Sig. $(F$-statistics $)$ & 0.000 & & 0.000 & & 0.000 & & 0.000 & & \\
\hline No. of observations & 408 & & 408 & & 408 & & 408 & & \\
\hline \multicolumn{9}{|c|}{ Note(s): **Significant at the $1 \%$ level; *Significant at the $5 \%$ level } & Regression resu \\
\hline
\end{tabular}

withholds information from stakeholders. This can be attributed to the fact that the companies' motives for disclosure are reduced because the block holder ownership can access information from the company's internal sources (Elfeky, 2017; Kolsi, 2017). This result is consistent with the notion that dispersion of ownership enhances disclosure and governance. These results the researchers agreed upon previously (e.g. Shin et al., 202; Yu et al., 2020; Juhmani, 2013).

The results showed that family ownership does not significantly push companies towards sustainability disclosures and the associated environmental, social, and governance performance. It seems that attention is focused away from the aspirations of stakeholders. This result contradicts Chau and Gray's (2010) arguments that family ownership in companies reduces information asymmetry problems. In contrast, this result agrees with Rudyanto (2017), who denied any active role of family ownership. Regarding the control variables, the results indicate that the larger companies fulfill their responsibilities towards stakeholders, engage in issues of concern, and maintain the relationship with stakeholders through sustainability disclosure, which gives legitimacy to its existence. While the company's age is not considered one of the sustainability disclosure determinants, older companies may be regarded as having strong legitimacy and are no longer willing to provide more to modernize their legitimacy.

Considering the influential role of the board's independence, the results indicate that through Table 6, the positive impact of foreign ownership on the ESG disclosure quality. Still, the level of confidence has increased regarding the governance dimension at (0.001) and sustainability ESG as a whole at the level (0.000), and this can be explained that foreign owners cooperate extensively with independent boards to strengthen governance in the companies they manage, which is reflected in improving disclosure levels, which meets the aspirations of various stakeholders, where companies that include foreign investors are more vulnerable to pressure from stakeholders. This result supports the stakeholder theory that foreign owners contribute to improving corporate behavior in disclosure. Moreover, the results confirm the positive role of government ownership in promoting sustainability disclosure practices and their dimensions under high independence level for boards of directors (Zaid et al., 2020).

Governments, in general, seek to promote community development, and the Jordanian government is trying to implement parts of its sustainable development plan through its 


\begin{tabular}{|c|c|c|c|c|c|c|c|c|c|}
\hline \multirow{2}{*}{$\begin{array}{l}\text { JBSED } \\
2,1\end{array}$} & \multirow[b]{2}{*}{ Independent variables } & \multicolumn{2}{|c|}{ ENVD } & \multicolumn{2}{|c|}{ SOCD } & \multicolumn{2}{|c|}{ GOVD } & \multicolumn{2}{|c|}{ ESGD } \\
\hline & & Coef. & Sig. & Coef. & Sig. & Coef. & Sig. & Coef. & Sig. \\
\hline \multirow[b]{5}{*}{60} & FOROWN & 1.449 & $0.016^{*}$ & 1.527 & $0.014^{*}$ & 1.269 & $0.001 * *$ & 1.459 & $0.000 * *$ \\
\hline & STAOWN & 1.514 & $0.002 *$ & 1.618 & $0.015^{*}$ & 1.874 & $0.010^{*}$ & 1.692 & $0.003^{*}$ \\
\hline & MANOWN & -1.506 & 0.413 & -3.615 & 0.157 & -2.407 & 0.686 & -4.147 & 0.446 \\
\hline & BLKOWN & -1.218 & 0.259 & -1.369 & 0.945 & -1.327 & 0.468 & -1.459 & 0.479 \\
\hline & FAOWN & -0.338 & 0.231 & 2.177 & $0.027^{*}$ & 1.925 & $0.033^{*}$ & 0.394 & $0.025^{*}$ \\
\hline \multirow{11}{*}{$\begin{array}{l}\text { Table } 6 \text {. } \\
\text { The moderating effect } \\
\text { of board independence }\end{array}$} & BOIND & 1.096 & $0.028^{*}$ & 1.772 & $0.001^{* *}$ & 1.309 & $0.004 * *$ & 1.595 & $0.006^{* *}$ \\
\hline & COSZE & 2.964 & $0.031 *$ & 3.248 & $0.008^{* *}$ & 2.871 & $0.022^{*}$ & 2.388 & $0.024 *$ \\
\hline & COAGE & 0.864 & 0.492 & 0.525 & 0.485 & 0.239 & 0.451 & 0.926 & 0.516 \\
\hline & Year dummies & Include & & Include & & Include & & Include & \\
\hline & Industry dummies & Include & & Include & & Include & & Include & \\
\hline & Constant & 0.296 & 0.000 ** & 0.228 & $0.000^{* *}$ & 0.314 & $0.000 * *$ & 0.198 & 0.23 \\
\hline & Adj. $R$ square $\left(R^{2}\right)$ & $0.417^{* *}$ & & $0.328^{* * *}$ & & $0.282^{* *}$ & & 0.237 ** & \\
\hline & $F$-statistics & 20.127 & & 7.415 & & 6.129 & & 8.191 & \\
\hline & Sig. ( $F$-statistics) & 0.000 & & 0.000 & & 0.000 & & 0.000 & \\
\hline & No. of observations & 408 & & 408 & & 408 & & 408 & \\
\hline & \multicolumn{9}{|c|}{ Note(s): **Significant at the $1 \%$ level; *significant at the $5 \%$ level } \\
\hline
\end{tabular}

ownership of shares in public joint-stock companies; this motivates companies to report as much information on their ESG performance to various parties. This finding is consistent with the legitimacy perspective in that state ownership enhances the accountability and transparency system in companies, thus enhancing their legitimacy. On the other hand, the board independence role appears neutral in dealing with the factor of managerial ownership, as the findings did not result in any explanation towards the disclosure of sustainability and its three dimensions. Besides, the interaction of the board's independence contributed to limiting the negative impact of the block holder's ownership, especially concerning their attitudes towards social, environmental, and sustainability issues as a whole.

Additionally, the interaction between independent boards and family owners has contributed to improving their attitudes towards disclosing information related to corporate social performance, governance, and sustainability because independent boards realize the importance of disclosing information to preserve legitimacy and satisfy various stakeholders. It appears that the family owners interact positively with those propositions and the importance of better managing relationships with stakeholders to avoid more pressure in the future. The results show that independent directors hold favorable views of their stakeholders' expectations, and they are also highly qualified to manage relationships with stakeholders (Romano et al., 2020). Thus, independent directors support disclosure on sustainability, environmental and social performance, and corporate governance. Also, companies that guarantee greater independence for the board of directors are more transparent about disclosure. In general, it can say that board independence is an essential tool to enhance transparency and governance, reduce information asymmetry, and encourage sustainability-related initiatives and reporting on them to various stakeholders. Besides, independents directors are fully aware of legitimacy requirements and act following the applicable social contract to avoid any legitimacy gap that may affect the company's activities. This is consistent with the legitimacy theory, which suggests that the more independent the board of directors, the more the company maintains its legitimacy.

\section{Conclusions}

The current study investigated the impact of the ownership structure, including foreign ownership, state ownership, managerial ownership, block holder ownership, and family 
ownership on ESG disclosure practices in Jordan. Also, this study took board independence as a moderator factor to influence the ownership structure. Moreover, two regression models were relied on to illustrate ownership structure variables' effect in light of the boards with a high level of independence.

The findings revealed that independent boards stand by stakeholders' demands through their full awareness of the significance of communicating information regarding companies' environmental, social, and governance performance to avoid any tensions with stakeholders. Also, the independent boards seek to enhance their reputation through sustainability activities. The independent boards are fully aware of the importance of strengthening legitimacy, and they contribute to educating owners about ESG disclosure importance in gaining trust with stakeholders and enhancing legitimacy. On the other hand, it appears that foreign owners give outstanding support to the disclosure practices in the presence of independent boards. Additionally, the board's independence affects the family ownership attitudes by directing them by the necessity that their interests coincide with the interests of the rest of the stakeholders to be more positive. Furthermore, independent boards limit the negative impact and opportunism of the block holders. At the same time, it does not affect the managers' attitudes who own shares in the companies they manage.

The findings have produced important implications for many parties, such as regulators, policymakers, shareholders, investors, and stakeholders. These implications provide insights to regulators on the role of the current ownership structures of the industrial sector on disclosure practices of environmental, social, and governance performance, as regulators, in cooperation with policymakers, can develop a mechanism to promote foreign investment in Jordan by developing new legislation to facilitate the entry of foreign capital into in the country, which will contribute to economic development. Besides, legislators should also put in place more legislation that guarantees the boards' independence, which will contribute to developing disclosure and transparency practices and enhancing the performance of companies. Also, attention must be paid to the importance of ownership dispersal, as ownership concentration will often divert attention from the sustainability agenda and issues related to it. On the other hand, the stakeholders and shareholders should provide adequate support for the boards of directors' independence and pressure in this direction, as the independent boards work according to various stakeholders' aspirations.

As with most experimental studies, the current study has several limitations. Firstly, this study was limited to the industrial companies' sector. Therefore, future studies can deal with other sectors such as banks or non-financial companies. Also, the comparative studies for different sectors will be interesting. Secondly, the current study examined the ownership structure and its effect on ESG disclosure. Future researchers can investigate the impact of other dimensions such as governance or financial performance. The role of ownership structure can be investigated at the level of disclosure for other reporting methods, such as integrated reporting. Moreover, other theories such as Institutional theory and agency theory can be tested and linked to ESG disclosure practices through different dimensions.

\section{References}

Abu Qa'dan, M.B. and Suwaidan, M.S. (2019), "Board composition, ownership structure and corporate social responsibility disclosure: the case of Jordan”, Social Responsibility Journal, Vol. 15 No. 1, pp. 28-46.

Adeniyi, S. and Adebayo, H.O. (2018), "Effect of financial leverage on voluntary corporate social disclosure among listed firms on Nigerian stock exchange: a study of selected manufacturing firms", Academic Journal of Economic Studies, Vol. 4 No. 3, pp. 18-24.

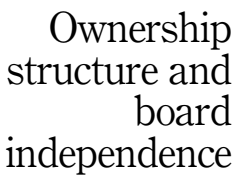

61 
JBSED 2,1

62

Akinwande, M.O., Dikko, H.G. and Samson, A. (2015), "Variance inflation factor: as a condition for the inclusion of suppressor variable (s) in regression analysis", Open Journal of Statistics, Vol. 5 No. 07, p. 754.

Al Amosh, H.A. (2021), "The role of governance attributes in corporate social responsibility (CSR) practices evidence from Jordan", in Alqatan, A., Hussainey, K. and Khlif, H. (Eds), Corporate Governance and its Implications on Accounting and Finance, IGI Global, pp. 255-279, doi: 10. 4018/978-1-7998-4852-3.ch012.

Al Amosh, H.A.M. and Mansor, N. (2018), "Sustainability and corporate reporting: a review on environmental and social accounting disclosure", International Journal of Accounting, Vol. 3 No. 8, pp. 78-87.

Al Amosh, H. and Mansor, N. (2020), "The implications of ownership structure on the environmental disclosure in Jordan”, International Journal of Academic Research in Business and Social Sciences, Vol. 10 No. 3, pp. 330-346.

$\mathrm{Al}$ Amosh, H. and Mansor, N. (2021), "Disclosure of integrated reporting elements by industrial companies: evidence from Jordan", Journal of Management and Governance, Vol. 25 No. 1, pp. 121-145.

Albawwat, A. and Basah, M. (2015), "Corporate governance and voluntary disclosure of interim financial reporting in Jordan”, Journal of Public Administration and Governance, Vol. 5 No. 2, pp. 100-127.

Al-Janadi, Y., Rahman, R.A. and Alazzani, A. (2016), "Does government ownership affect corporate governance and corporate disclosure?”, Managerial Auditing Journal, Vol. 31 Nos 8/9, pp. 871-890.

Alhazaimeh, A., Palaniappan, R. and Almsafir, M. (2014), "The impact of corporate governance and ownership structure on voluntary disclosure in annual reports among listed Jordanian companies", Procedia-Social and Behavioral Sciences, Vol. 129, pp. 341-348.

Alkhawaldeh, A.A. (2012), "Effects of family and foreign ownership structure on Jordanian credit risk assessments", International Research Journal of Finance and Economics, Vol. 90 No. 2012, pp. 92-113.

Alzoubi, E.S.S. (2016), "Ownership structure and earnings management: evidence from Jordan", International Journal of Accounting and Information Management, Vol. 24 No. 2, pp. 135-161.

Amman stock exchange (2016), "A guide manual on preparing sustainability reports", available at: https://www.ase.com.jo/.

Arouri, H., Hossain, M. and Muttakin, M.B. (2014), "Effects of board and ownership structure on corporate performance: evidence from GCC countries", Journal of Accounting in Emerging Economies, Vol. 4 No. 1, pp. 117-130.

Bae, S.M., Masud, M., Kaium, A. and Kim, J.D. (2018). "A cross-country investigation of corporate governance and corporate sustainability disclosure: a signaling theory perspective", Sustainability, Vol. 10 No 8, p. 2611.

Bansal, S., Lopez-Perez, M.V. and Rodriguez-Ariza, L. (2018). "Board independence and corporate social responsibility disclosure: the mediating role of the presence of family ownership", Administrative Sciences, Vol. 8 No 3, p. 33.

Barako, D.G., Hancock, P. and Izan, H.Y. (2006), "Factors influencing voluntary corporate disclosure by Kenyan companies", Corporate Governance: An International Review, Vol. 14 No. 2, pp. 107-125.

Campbell, D., Craven, B. and Shrives, P. (2003), "Voluntary social reporting in three FTSE sectors: a comment on perception and legitimacy", Accounting, Auditing and Accountability Journal, Vol. 16 No. 4, pp. 558-581.

Chau, G. and Gray, S.J. (2010), "Family ownership, board independence and voluntary disclosure: evidence from Hong Kong", Journal of International Accounting, Auditing and Taxation, Vol. 19 No. 2, pp. 93-109. 
Ching, H.Y. and Gerab, F. (2017), "Sustainability reports in Brazil through the lens of signaling, legitimacy and stakeholder theories", Social Responsibility Journal, Vol. 13 No. 1, pp. 95-110.

Cucari, N., Esposito de Falco, S. and Orlando, B. (2018), "Diversity of board of directors and environmental social governance: evidence from Italian listed companies", Corporate Social Responsibility and Environmental Management, Vol. 25 No. 3, pp. 250-266.

Deegan, C. (2002), "Introduction: the legitimizing effect of social and environmental disclosures. Accounting", Auditing and Accountability Journal, Vol. 15 No. 3, pp. 282-311.

Deegan, C. (2013), Financial Accounting Theory/Craig Deegan, 4th ed., McGraw-Hill Education, North Ryde, NSW.

Deegan, C. and Unerman, J. (2006), Financial Accounting Theory, European ed., McGraw-Hill Education, Maidenhead.

Elfeky, M.I. (2017), "The extent of voluntary disclosure and its determinants in emerging markets: evidence from Egypt", The Journal of Finance and Data Science, Vol. 3 Nos 1-4, pp. 45-59.

Eng, L.L. and Mak, Y.T. (2003), "Corporate governance and voluntary disclosure", Journal of Accounting and Public Policy, Vol. 22 No. 4, pp. 325-345.

Eugénio, T.P., Lourenco, I.C. and Morais, A.I. (2013), "Sustainability strategies of the company TimorL: extending the applicability of legitimacy theory", Management of Environmental Quality: An International Journal, Vol. 24 No. 5, pp. 570-582.

Fernández-Gago, R., Cabeza-García, L. and Nieto, M. (2018), "Independent directors' background and CSR disclosure", Corporate Social Responsibility and Environmental Management, Vol. 25 No. 5 , pp. 991-1001.

Fuzi, S.F.S., Halim, S.A.A. and Julizaerma, M.K. (2016), "Board independence and firm performance", Procedia Economics and Finance, Vol. 37, pp. 460-465.

Grassa, R., Moumen, N. and Hussainey, K. (2020), "Do ownership structures affect risk disclosure in Islamic banks? International evidence", Journal of Financial Reporting and Accounting, Vol. 19 No. 3, pp. 369-391.

Gujarati, D.N., Porter, D.C. and Gunasekar, S. (2012), Basic Econometrics, 5th ed., Tata McGraw-Hill Education, New Delhi.

Guo, M. and Zheng, C. (2021), "Foreign ownership and corporate social responsibility: evidence from China”, Sustainability, Vol. 13 No. 2, p. 508.

Hazaea, S.A., Zhu, J., Al-Matari, E.M., Senan, N.A.M., Khatib, S.F.A. and Ullah, S. (2021), "Mapping of internal audit research in China: a systematic literature review and future research agenda", Cogent Business and Management, Vol. 8 No. 1, p. 1938351.

Hörisch, J., Schaltegger, S. and Freeman, R.E. (2020), "Integrating stakeholder theory and sustainability accounting: a conceptual synthesis", Journal of Cleaner Production, Vol. 275, p. 124097.

Husted, B.W. and de Sousa-Filho, J.M. (2019), "Board structure and environmental, social, and governance disclosure in Latin America”, Journal of Business Research, Vol. 102, pp. 220-227.

Iannotta, G., Nocera, G. and Sironi, A. (2007), "Ownership structure, risk and performance in the European banking industry", Journal of Banking and Finance, Vol. 31 No. 7, pp. 2127-2149.

Ilhan-Nas, T., Okan, T., Tatoglu, E., Demirbag, M., Wood, G. and Glaister, K.W. (2018), "Board composition, family ownership, institutional distance and the foreign equity ownership strategies of Turkish MNEs", Journal of World Business, Vol. 53 No. 6, pp. 862-879.

Jalila, S. and Devi, J. (2012), "Ownership structure effect on the extent of segment disclosure: evidence from Malaysia”, Procedia Economics and Finance, Vol. 2, pp. 247-256.

Jizi, M. (2017), "The influence of board composition on sustainable development disclosure", Business Strategy and the Environment, Vol. 26 No. 5, pp. 640-655.
Ownership structure and board independence 
JBSED

2,1

64

Juhmani, O.I. (2013). "Ownership structure and corporate voluntary disclosure: evidence from Bahrain”, International Journal of Accounting and Financial Reporting, Vol. 3 No 2, p. 133.

Khan, A., Muttakin, M.B. and Siddiqui, J. (2013), "Corporate governance and corporate social responsibility disclosures: evidence from an emerging economy", Journal of Business Ethics, Vol. 114 No. 2, pp. 207-223.

Khan, T.M., Gang, B., Fareed, Z. and Khan, A. (2021), "How does CEO tenure affect corporate social and environmental disclosures in China? Moderating role of information intermediaries and independent board”, Environmental Science and Pollution Research, Vol. 28 No. 8, pp. 9204-9220.

Khatib, S.F.A., Abdullah, D., Hendrawaty, E. and Elamer, A.A. (2021), "A bibliometric analysis of cash holdings literature : current status, development, and agenda for future research", Management Review Quarterly, p. 0123456789.

Khlif, H., Ahmed, K. and Souissi, M. (2017), "Ownership structure and voluntary disclosure: a synthesis of empirical studies”, Australian Journal of Management, Vol. 42 No. 3, pp. 376-403.

Kolsi, M.C. (2017), "The determinants of corporate voluntary disclosure policy", Journal of Accounting in Emerging Economies, Vol. 7 No. 2, pp. 249-265.

Krippendorff, K. (2018), Content Analysis: An Introduction to its Methodology, Sage, New York.

Lagasio, V. and Cucari, N. (2019), "Corporate governance and environmental social governance disclosure: a meta-analytical review", Corporate Social Responsibility and Environmental Management, Vol. 26 No. 4, pp. 701-711.

Li, D., Huang, M., Ren, S., Chen, X. and Ning, L. (2018), "Environmental legitimacy, green innovation, and corporate carbon disclosure: evidence from CDP China 100", Journal of Business Ethics, Vol. 150 No. 4, pp. 1089-1104.

Lindblom, C.K. (1994). "The implications of organizational legitimacy for corporate social performance and disclosure", Critical Perspectives on Accounting Conference, New York, Vol. 120 No 2.

Lu, F., Kozak, R., Toppinen, A., D’Amato, D. and Wen, Z. (2017). "Factors influencing levels of CSR disclosure by forestry companies in China”, Sustainability, Vol. 9 No 10, p. 1800.

Mahmood, Z., Ahmad, Z., Ali, W. and Ejaz, A. (2017), "Does environmental disclosure relate to environmental performance? Reconciling legitimacy theory and voluntary disclosure theory", Pakistan Journal of Commerce and Social Sciences (PJCSS), Vol. 11 No. 3, pp. 1134-1152.

Manes-Rossi, F., Tiron-Tudor, A., Nicolò, G. and Zanellato, G. (2018). "Ensuring more sustainable reporting in Europe using non-financial disclosure-de facto and de jure evidence", Sustainability, Vol. 10 No 4, p. 1162.

Moloi, T. and Marwala, T. (2020), "The legitimacy theory and the legitimacy gap", Artificial Intelligence in Economics and Finance Theories, Springer, Cham, pp. 103-113.

Monk, A. (2009), "Recasting the sovereign wealth fund debate: trust, legitimacy, and governance", New Political Economy, Vol. 14 No. 4, pp. 451-468.

Myers, R.H. (1990), Classical and Modern Regression with Applications, Duxbury Press, Belmont, CA, Vol. 2, p. 488.

Negre, E., Verdier, M.A., Cho, C.H. and Patten, D.M. (2017), "Disclosure strategies and investor reactions to downsizing announcements: a legitimacy perspective", Journal of Accounting and Public Policy, Vol. 36 No. 3, pp. 239-257.

Oanh, T.T.K., Hien, D.T.T., Anh, H.T.P. and Ha, D.T.T. (2021), "Ownership structure and firm performance: empirical study in Vietnamese stock exchange", Data Science for Financial Econometrics, Springer, Cham, pp. 353-367.

Ortas, E., Álvarez, I. and Zubeltzu, E. (2017). "Firms' board independence and corporate social performance: a meta-analysis", Sustainability, Vol. 9 No 6, p. 1006.

Pajuelo Moreno, M.L. and Duarte-Atoche, T. (2019). "Relationship between sustainable disclosure and performance - an extension of Ullmann's model”, Sustainability, Vol. 11 No 16, p. 4411. 
Patten, D.M. (2019), "Seeking legitimacy", Sustainability Accounting, Management and Policy Journal, Vol. 11 No. 6, pp. 1009-1021.

Pucheta-Martínez, M.C. and Gallego-Álvarez, I. (2019), "An international approach of the relationship between board attributes and the disclosure of corporate social responsibility issues", Corporate Social Responsibility and Environmental Management, Vol. 26 No. 3, pp. 612-627.

Raimo, N., Vitolla, F., Marrone, A. and Rubino, M. (2020), "The role of ownership structure in integrated reporting policies", Business Strategy and the Environment, Vol. 29 No. 6, pp. 2238-2250.

Rees, W. and Rodionova, T. (2015), "The influence of family ownership on corporate social responsibility: an international analysis of publicly listed companies", Corporate Governance: An International Review, Vol. 23 No. 3, pp. 184-202.

Romano, M., Cirillo, A., Favino, C. and Netti, A. (2020). "ESG (environmental, social and governance) performance and board gender diversity: the moderating role of CEO duality", Sustainability, Vol. 12 No 21, p. 9298.

Rudyanto, A. (2017), "State ownership, family ownership, and sustainability report quality: the moderating role of board effectiveness", Accounting and Finance Review (AFR), Vol. 2 No. 2, pp. 15-25.

Rustam, A., Wang, Y. and Zameer, H. (2019), "Does foreign ownership affect corporate sustainability disclosure in Pakistan? A sequential mixed methods approach", Environmental Science and Pollution Research, Vol. 26 No. 30, pp. 31178-31197.

Saini, N. and Singhania, M. (2019), "Performance relevance of environmental and social disclosures", Benchmarking: An International Journal, Vol. 26 No. 6, pp. 1845-1873.

Samaha, K. and Dahawy, K. (2011), "An empirical analysis of corporate governance structures and voluntary corporate disclosure in volatile capital markets: the Egyptian experience", International Journal of Accounting, Auditing and Performance Evaluation, Vol. 7 Nos 1-2, pp. 61-93.

Samaha, K., Dahawy, K., Hussainey, K. and Stapleton, P. (2012), "The extent of corporate governance disclosure and its determinants in a developing market: the case of Egypt", Advances in Accounting, Vol. 28 No. 1, pp. 168-178.

Schaltegger, S., Bennett, M. and Burritt, R. (2006), "Sustainability accounting and reporting: development, linkages and reflection. An introduction", Sustainability Accounting and Reporting, Springer, Dordrecht, pp. 1-33.

Sengupta, P. (2004), "Disclosure timing: determinants of quarterly earnings release dates", Journal of Accounting and Public Policy, Vol. 23 No. 6, pp. 457-482.

Sharma, P., Panday, P. and Dangwal, R.C. (2020), "Determinants of environmental, social and corporate governance (ESG) disclosure: a study of Indian companies", International Journal of Disclosure and Governance, Vol. 17 No. 4, pp. 208-217.

Shin, J.E., Yoo, S.W. and Lee, G. (2020). "The effects of blockholder dispersion on the informativeness of earnings: evidence from Korea”, Sustainability, Vol. 12 No 22, p. 9328.

Suchman, M.C. (1995), "Managing legitimacy: strategic and institutional approaches", Academy of Management Review, Vol. 20 No. 3, pp. 571-610.

Younas, N., UdDin, S., Awan, T. and Khan, M.Y. (2021), "Corporate governance and financial distress: Asian emerging market perspective", Corporate Governance: The International Journal of Business in Society, Vol. 21 No. 4, pp. 702-715.

Yu, H.C., Kuo, L. and Ma, B. (2020), "The drivers of corporate water disclosure in enhancing information transparency", Sustainability, Vol. 12 No 1, p. 385.

Zaid, M.A., Abuhijleh, S.T. and Pucheta-Martínez, M.C. (2020), "Ownership structure, stakeholder engagement, and corporate social responsibility policies: the moderating effect of board independence", Corporate Social Responsibility and Environmental Management, Vol. 27 No. 3, pp. 1344-1360.

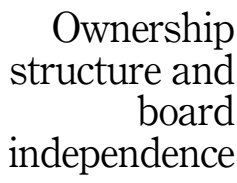

65 
JBSED

2,1

66
Zamil, I.A., Ramakrishnan, S., Jamal, N.M., Hatif, M.A. and Khatib, S.F.A. (2021), "Drivers of corporate voluntary disclosure: a systematic review", Journal of Financial Reporting and Accounting, Vol. ahead-of-print No. ahead-of-print, doi: 10.1108/JFRA-04-2021-0110.

\section{Corresponding author}

Hamzeh Al Amosh can be contacted at: hamza_omosh@yahoo.com

For instructions on how to order reprints of this article, please visit our website: www.emeraldgrouppublishing.com/licensing/reprints.htm Or contact us for further details: permissions@emeraldinsight.com 